\title{
Ocena parametryczna jednostek naukowych w Polsce w roku 2017 w obszarze nauk humanistycznych i społecznych prowadzących badania naukowe i kształcenie akademickie w zakresie pedagogiki
}

\begin{abstract}
Abstrakt
W artykule przedstawiono wyniki oceny parametrycznej jednostek naukowych z obszaru badań pedagogicznych z roku 2017. Przybliżono zasady i parametry oceny i jej uwarunkowania. Tą problematyką zajmuje się naukometria - nowa dziedzina badań porównawczych w obszarze komunikacji naukowej. Ukazano nowe wskaźniki analizy dokumentów źródłowych. Zwieńczeniem analizy są wnioski istotne do modernizacji praktyki z zakresu polityki naukowej państwa oraz polityki poszczególnych jednostek organizacyjnych uczelni jak też instytutów badawczych.
\end{abstract}

Słowa kluczowe: ocena parametryczna, jednostki naukowe, polityka naukowa, komunikacja naukowa, wskaźniki i indeksy w naukoznawstwie.

\section{Parametric assessment of research units in Poland in 2017, in the field of humanities and social sciences, conducting research and academic education in pedagogy}

\begin{abstract}
The article presents the results of the parametric assessment of research units in the field of pedagogical research carried out in 2017. It outlines the principles and parameters of the assessment and its conditions. This area is covered by science metrics - a new field of comparative research in scientific communication. The article further presents new indicators for the analysis of source documents and proposes a conclusion that is relevant for the modernization of the state scientific policy and the policy of particular organizational units of universities and research institutes.
\end{abstract}

Keywords: parametric assessment, research units, scientific policy, scientific communication, indicators and indexes in science.

* Uniwersytet Warmińsko-Mazurski w Olsztynie. 


\section{Wstęp}

W artykule omawiam wyniki oceny parametrycznej uczelni w ujęciu strukturalnym jak i jednostek naukowych prowadzących studia i badania naukowe z zakresu pedagogiki. Jest to fragment szerszego oglądu nauki w Polsce, określonego na podstawie dokumentów generowanych przez różne organy państwa, monitorujące rozwój badań i kształcenia akademickiego.

Problematyka wartości i wartościowania w nauce wymaga gruntownego namysłu zarówno w perspektywie różnych nurtów i odmian myślenia w filozofii, jak też z punktu widzenia pedagogiki. A tutaj ocena i ocenianie są podstawowymi kategoriami przede wszystkim praktyki edukacyjnej. Wartość i ocena, wartościowanie i ocenianie to dwie pary pojęć często zastępowalnych jedne przez drugie w dyskursie naukowym. Ale są bytowo ugruntowane w zupełnie innych perspektywach teoretycznych i systemach aksjologicznych. Ich oczyszczenie logiczne i merytoryczne wydaje się zabiegiem koniecznym przed dalszymi pracami podejmowanymi przez organy rządowe w sprawie oceny parametrycznej jednostek naukowych w kolejnych latach.

Problem drugi wiąże się z zamysłem rządu, aby powiązać wyniki oceny parametrycznej z uprawnieniami naukowymi instytucji naukowych oraz akademickich. Rząd proponuje, aby te jednostki, którym Komitet Ewaluacji Jednostek Naukowych przyzna najwyższe kategorie, posiadały automatycznie uprawnienia do nadawania stopnia doktora habilitowanego (kategoria $\mathrm{A}+, \mathrm{A}$ ) oraz stopnia doktora $(\mathrm{B}+$ ). Nie bierze się pod uwagę takiego oto faktu, że małe placówki badawcze, zatrudniające kadrę emerytowanych profesorów, ale uzyskujących znaczącą liczbę punktów za publikacje naukowe, pozyskiwane granty i znakomitą współpracę z podmiotami gospodarczymi i społecznymi działającymi na lokalnym rynku pracy, a nadto efektywnie współpracujące $\mathrm{z}$ instytucjami międzynarodowymi mogą uzyskać takie uprawnienia, a inne dotąd uznane placówki, posiadające jednak znaczną liczbę pracowników i chwilowy spadek efektywności w działalności naukowo-badawczej, mogą takie uprawnienia stracić. Zatem obok wyników oceny parametrycznej konieczne jest kryterium drugie, kadrowe. Chodzi o ustalenie także minimalnej liczby nauczycieli akademickich posiadających tytuł naukowy i stopień doktora habilitowanego jako środowiska naukowego zdolnego do przeprowadzania postępowań habilitacyjnych i o uzyskanie tytułu naukowego. W danej placówce powinni być zatrudnieni specjaliści z różnych obszarów badań realizowanych w obrębie danej dziedziny czy dyscypliny naukowej.

Od ponad pół wieku działalność naukowo-badawcza podlega wszechstronnej ocenie. W poszczególnych państwach świata powołano specjalistyczne komitety zajmujące się analizą dorobku naukowego, potencjału badawczego, wszelkimi osiągnięciami naukowców skupionych w poszczególnych uczelniach czy instytutach badawczych. Istnieje dzisiaj wiele podmiotów realizujących projekty badawcze. Do XIX w. badania naukowe prowadzono głównie w uczelniach, niekiedy 
samodzielnie przez poszczególnych uczonych łożących własne środki finansowe na realizację swoich pasji poznawczych. Ale już w XIX stuleciu pojawiły się stowarzyszenia naukowe, akademie nauk, akademie umiejętności grupujące wybitnych uczonych z poszczególnych dziedzin nauki. Uzyskiwali oni wsparcie na realizację poszczególnych projektów naukowo-badawczych z budżetu państwa. Zaś w XX w. powstawały liczne laboratoria i specjalistyczne pracownie badawcze prowadzone przez wielkie korporacje gospodarcze.

Rynek badań naukowych stał się bardzo szeroki. Nieustannie zwiększająca się liczba podmiotów realizujących badania naukowe i publikujących ich wyniki $\mathrm{w}$ czasopismach albo $\mathrm{w}$ formie monografii doprowadziła do rozwoju wielu zakładów edytorskich, poligraficznych i specjalistycznych czasopism naukowych. Pojawiła się konkurencja zarówno właściwa dla podmiotów gospodarczych, bo związana $\mathrm{z}$ racjonalizacją kosztów publikacji, jak też konkurencja jakościowa. Jedne redakcje czasopism przyjmowały prace tylko najlepsze, najwyżej ocenione przez recenzentów, inne redakcje prace przeciętne, jeśli tylko zdołano zapewnić wystarczającą ilość materiału do zamknięcia numeru pisma i jego kolejną edycję.

Ze względu na niewielki zasięg dystrybucji pism naukowych, bo przeznaczane są głównie dla specjalistów z określonej dziedziny nauki, mechanizm rynkowy tutaj nie działał. Pisma były dotowane przez organy państwa albo korporacje gospodarcze, stąd też ewaluacja zawartości ich treści stała się podstawą ustalania jego marki na rynku wewnętrznym świata naukowego. Uczeni na ogół „wiedzieli”, które czasopisma i wydawnictwa naukowe publikują ważne teksty, a które przeciętne. $\mathrm{Z}$ czasem ten samorodny ruch oceniania poziomu edytorstwa $\mathrm{w}$ świecie akademickim stał się bardziej wymierny. Pojawiła się też nowa dyscyplina naukowa związana z komunikacją piśmienniczą - bibliologia i informatologia naukowo-techniczna (Sordylowa 1998; Skalska-Zlat 2015).

\section{Zasady oceny działalności badawczej jednostek naukowych}

Wymiernym efektem oceny placówek naukowych i zatrudnionych w nich badaczy w XX w. są nowe jednostki pomiaru osiągnięć naukowych. Efekty badań zamieszczone w publikacjach naukowych poddano wtórnej analizie ze względu już nie tyle na zawartość merytoryczną, bo tę potrafili właściwie ocenić wyłącznie specjaliści z danego obszaru nauki, ale ze względu na prestiż czasopisma, w którym publikowano prace, a nadto na wpływ danego autora na innych uczestników procesów badawczych odwołujących się w swoich studiach do prac konkretnego badacza. I tak powstała bibliometria (Nowak 2008; Piotrowski 2017) - kolejna nowa dziedzina wiedzy zajmująca się badaniami naukoznawczymi. Badacze z obszaru tej dyscypliny wiedzy zajmują się matematycznym opisem piśmiennictwa naukowego. Stosują różnorodne metody matematyczne i statystyczne do komunikacji piśmien- 
niczej, oceny dorobku badaczy umieszczanego na tradycyjnych i nowoczesnych nośnikach wiedzy.

W bibliometrii istotne wydają się dwa wskaźniki opisujące dorobek naukowy poszczególnych badaczy (Gil 2014). Pierwszy z nich to wskaźnik wpływu, oddziaływania treści artykułów zamieszczonych w danym czasopiśmie na innych badaczy, w pewien sposób można go określić też miarą cytowalności (Impact Factor). Jest to zatem miernik siły oddziaływania i prestiżu czasopism naukowych. Określa się nim znaczenie, wpływ danego badacza i pisma, w którym publikuje, na innych uczonych. Liczba cytowań jego publikacji przez innych naukowców jest miarą znaczenia i wartością owego badacza wśród innych przedstawicieli z tego samego obszaru wiedzy.

Drugi wskaźnik nazywany jest Indeksem Hirscha. Określa on znaczenie i wpływ wszystkich prac danego autora na innych badaczy. Wskazuje zarówno zasób ilościowy publikacji danego autora, jak i przywoływanie jego konkretnych dzieł przez innych uczonych. Jego wielkość jest wyższa, jeśli dana osoba publikuje mniej prac, ale o wielkiej cytowalności. Stąd jakaś ważka publikacja naukowa, której treść wywiera znaczący wpływ na innych uczonych, może zaważyć o wyjątkowej pozycji jej autora w rankingu nauki, chociaż ten później opublikuje ledwie kilka prac o znacznie mniejszym znaczeniu dla badań naukowych z danej dyscypliny wiedzy. Krytycy teorii zaproponowanej przez J. Hirscha pokazują różne niedoskonałości także w stosowanych tutaj miarach statystycznych. Jednak ów indeks h, stał się jednym z istotnych elementów branych pod uwagę przy całościowej ocenie dorobku danego badacza zarówno w jego karierze akademickiej, jak też w konkursach o dofinansowanie projektów badawczych.

W Polsce w ocenie parametrycznej uwzględnia się prace naukowe opublikowane w czasopismach znajdujących się na Liście Filadelfijskiej - Journal Cititation Reports (JCR), czyli w bazie uznanych za najlepsze na świecie czasopism naukowych w Instytucie Informacji Naukowej w Filadelfii. Znajduje się tam około 10 tysięcy tytułów czasopism z całego świata redagowanych przede wszystkim w języku angielskim. Określa się dla każdego z nich wskaźnik IF (Impact Factor), czyli domniemanie rzeczywistego wpływu wywieranego na „produkcję naukową” w danej dyscyplinie czy dziedzinie nauki.

Czasopisma ze wskaźnikiem IF stanowią tak zwaną listę A czasopism - o najwyższej punktacji, z perspektywy polskiego uczonego (od 15 do 50 punktów). Z kolei czasopisma z listy B, wydawane w języku polskim o znacznie mniejszym oddziaływaniu na naukę światową uzyskują zdecydowanie niższą punktację i mieszczą się w przedziale od 1 do 15 punktów, zaś czasopisma na liście C mają zasięg głównie europejski i też nieco wyższą punktację niż pisma polskojęzyczne (od 10 do 25 punktów). Oznacza to, że każdy autor za opublikowanie pracy naukowej w czasopiśmie znajdującym się na konkretnej liście uzyskuje za swoją pracę liczbę punktów, jaka została przypisana temu pismu przez zespół ekspertów $\mathrm{z}$ danego obszaru nauki. 
Zarówno Lista Filadelfijska, jak i europejska baza ERIH w przekonaniu niektórych badaczy są przykładami neokolonializmu w nauce, przykładami przemocy symbolicznej (Bourdieu 2009; Sztander-Sztanderska 2010; Zielińska-Kostyło 2011). Podstawowym środkiem komunikacji w nauce stał się język angielski. Zastąpił niejako średniowieczną łacinę jako ówczesną płaszczyznę porozumiewania się uczonych z różnorodnych uniwersytetów. Jednak lingwiści i miłośnicy języka ojczystego wskazują na nieprzekładalność doświadczenia człowieka zapisującego swoje doznania w lokalnym języku. Subtelne analizy lingwistyczne zostają zastępowane prostymi komunikatami o znacznym nasyceniu liczbami, wykresami czy wzorami właściwymi dla komunikacji w obrębie danej dyscypliny naukowej. Język nauki pozbawiony jest niuansów, odcieni znaczeniowych, posmaku dowcipu i żartu, wyrażanych skrajnych emocji. Nauka współczesna nie polega wszak na oczyszczaniu komunikatów z ich rozlicznych interpretacji, skojarzeń znaczeniowych czy wręcz wyrażanych emocji. Te zaś możliwe są tylko w języku ojczystym uczonego. Nawet najwybitniejsi tłumacze dzieł literackich jak i tekstów naukowych, zwłaszcza z obszaru humanistyki, wskazują na trudności we właściwym oddaniu wszystkich barw i smaków wypowiedzi językowej danego autora. Aby zrozumieć w pełni jego tekst, trzeba żyć, a nawet mieszkać w danym środowisku i doświadczać tych samych emocji wywoływanych istotnymi dla ludzi wydarzeń historycznych (Krzemieniowa 1986; Górniewicz, Piotrowski 2014b).

W rozporządzeniu ministra właściwego do spraw nauki oraz w komunikacie dotyczącym wykazu czasopism punktowanych (Komunikat Ministra Nauki... 2015) uwzględniono także klasyczne formy publikowania prac naukowych, zwłaszcza z humanistyki, jak monografie autorskie, monografie wieloautorskie, zwane kiedyś pracami zbiorowymi przygotowanymi pod redakcją jakiegoś naukowca, i osiągnięcia pomniejsze. Każda praca naukowa musi też spełniać warunek objętości tekstowej i inne kryteria określone przez redakcje czasopism czy wydawnictw naukowych, związane na przykład z przygotowaniem streszczeń w językach obcych, opracowania redakcyjnego tekstu, jego objętości formalnej, sporządzania przypisów, bibliografii czy też układu graficznego.

Parametryzacja jest procesem porównywania prawdziwych wartości opisujących jednostki naukowe. Parametrem jest wartość stała służąca do opisu danej zbiorowości, wielkość charakterystyczna dla danego procesu (Arnold 2011).

W kompleksowej ocenie polskich jednostek naukowych z roku 2017 (Rozporządzenie Ministra Nauki... 2016) wzięto pod uwagę cztery kryteria, które zostały zamieszczone w rozporządzeniu ministra właściwego do spraw nauki. Do zbioru tych jednostek należą wydziały szkół wyższych albo całe szkoły wyższe, jeśli prowadzą w miarę jednorodną działalność naukowo-dydaktyczną, instytuty badawcze Polskiej Akademii Nauk, jednostki badawczo-rozwojowe poszczególnych ministerstw oraz pozostałe jednostki, niekiedy unikatowe, regionalne o niewielkim zasięgu i małej liczbie osób zatrudnionych do realizacji konkretnych projektów badawczych. 
Kryterium pierwsze, stanowiące około 65\% kompleksowej oceny jednostki naukowej, stanowią osiągnięcia naukowe lub artystyczne poszczególnych osób, zatrudnionych $\mathrm{w}$ danej placówce. Są to publikacje naukowe, patenty, wynalazki i dzieła artystyczne, którym przypisuje się określoną liczbę punktów, zgodnie z treścią rozporządzenia ministra. Kryterium drugie stanowi potencjał naukowy ocenianej jednostki. Wlicza się tutaj tytuły i stopnie naukowe własnych pracowników naukowych lub w zakresie sztuki, liczbę przeprowadzonych postępowań o nadanie tytułu profesora, stopnia doktora habilitacyjnego czy nadane stopnie doktora w określonej dyscyplinie, dziedzinie naukowej lub artystycznej, przede wszystkim zaś mobilność kadry naukowej i pozyskane środki na badania naukowe. Kryterium to stanowi 15\% kompleksowej oceny w przypadku nauk humanistycznych i społecznych, a $10 \% \mathrm{w}$ pozostałych grupach nauk. Kryterium trzecie to praktyczne efekty działalności naukowej i artystycznej, związane z realizacją projektów badawczych i artystycznych, aktywnością naukową wspierającą działalność poszczególnych przedsiębiorstw czy instytucji społecznych i kulturalnych. Wlicza się tutaj współpracę jednostki naukowej z otoczeniem społecznym i gospodarczym, podmiotów działających w środowisku lokalnym. Mieszczą się tu badania zamawiane przez przedsiębiorstwa, administrację regionalną, placówki kulturalne, oświatowe, z zakresu pracy socjalnej oraz stowarzyszenia. Zaś do kryterium czwartego zaliczono pozostałe efekty działalności naukowej i artystycznej ocenianej placówki. W konkretnym wymiarze władze jednostki wskazywały 10 najważniejszych wydarzeń, osiągnięć pracowników danej instytucji, w tym uzyskane nagrody w konkursach, prestiżowe wyróżnienia, szczególnie wybitne dzieła naukowe czy artystyczne. Trzy pierwsze wskaźniki mają wymiar ilościowy, zaś czwarty jest najbardziej uznaniowym kryterium oceny placówki naukowej. Ale też na ten wskaźnik przypada 15\% owej kompleksowej oceny parametrycznej danej jednostki organizacyjnej.

Podstawą określania liczby uzyskanych punktów było sprawozdanie w formie ankiety ewaluacyjnej przygotowanej przez władze ocenianej jednostki. Wliczano tutaj publikacje umieszczone w komputerowej bazie expertus jako osiągnięcia poszczególnych badaczy, dokonane przez wyspecjalizowane służby akademickie, specjalistów z zakresu bibliometrii. Potencjał kadrowy ustala się także na podstawie informacji zamieszczonych $\mathrm{w}$ bazie nauki polskiej Polon. Mieszczą się tam nazwiska z tytułami i stopniami naukowymi czynnych naukowców, zatrudnionych w polskich placówkach badawczych. Zaś na podstawie sprawozdań przesyłanych do Centralnej Komisji ds. Stopni i Tytułów ustala się liczbę przeprowadzonych postępowań o nadanie tytułu profesora, stopnia doktora habilitowanego oraz doktora w uprawnionych jednostkach naukowych w danym roku kalendarzowym.

Liczbę i wartość projektów badawczych finansowanych przez Narodowe Centrum Nauki (projekty z zakresu badań podstawowych) oraz Narodowe Centrum Badań i Rozwoju (projekty z zakresu badań aplikacyjnych i wdrożeniowych) określa się na podstawie danych zamieszczanych na stronach internetowych tych 
instytucji. Projekty pomniejsze uzyskane od podmiotów gospodarczych znajdują się w bazie danej jednostki. Władze tej placówki podpisały stosowne umowy o finansowaniu konkretnych zadań badawczych i rozwojowych.

Niezwykle istotnym elementem w kryterium pierwszym, czyli ustalenia wskaźnika osiągnięć naukowych oraz w zakresie sztuki, jest określenie liczby osób zatrudnionych w danej placówce na stanowiskach naukowo-badawczych lub naukowo-dydaktycznych. Wylicza się tak zwaną liczbę „N”, czyli średnią etatów w danym okresie sprawozdawczym. Od tej liczby faktycznych etatów odlicza się nadto osoby, które z różnych przyczyn nie opublikowały żadnej pracy w punktowanych czasopismach naukowych czy w innej formie. Stanowią one tak zwaną liczbę „N - 0” (N - zero). Pomniejszają zatem wartość rzeczywistą dorobku naukowego danej jednostki organizacyjnej. Takie rozumienie owej liczby „N” wymusza większą aktywność publikacyjną zatrudnionych w placówce pracowników naukowych. Każdy z nich w okresie sprawozdawczym powinien być autorem co najmniej jednej pracy zamieszczonej w punktowanym czasopiśmie albo monografii wieloautorskiej.

Wszystkie publikacje naukowe napisane przez pracowników danej jednostki i przypisane do niej (w przypadku, kiedy dana osoba pracuje w kilku ocenianych placówkach, określa ona, które prace przypisuje do tej, a które do innej jednostki organizacyjnej) zostają umieszczone na liście publikacji w kolejności od tych, które uzyskały najwyższą liczbę punktów, do tych najniżej punktowanych. Liczba „N” jest istotna do określenia ostatecznej liczby prac wchodzących do ankiety ewaluacyjnej. Ministerstwo nauki określa wysokość liczbową owego współczynnika. W ocenie parametrycznej z roku 2017 ustalono 3 „N”. Jeśli zatem jednostka naukowa zatrudniała 100 pracowników w okresie sprawozdawczym, to liczba prac wchodzących do ankiety stanowiła 300 najwyżej punktowanych. Suma punktów z tych 300 prac była dzielona przez „N”, czyli w tym przypadku 100. Jednostka uzyskiwała w kryterium pierwszym określoną wartość osiągnięć naukowych i artystycznych. Jednak w praktyce owa idealna liczba „N” bywa korygowana o wartość liczby „N - zero”). Jeśli zatem spośród przeliczeniowych 100 etatów 5 osób w okresie sprawozdawczym nie opublikowało żadnej pracy w czasopismach punktowanych lub w monografiach wieloautorskich, to wówczas skorygowana liczba prac wchodzących do licznika wynosiła 290, ale dzielnik stanowił wartość 100 (3N - 2Nzero).

Osoby, które w tym czasie nie opublikowały żadnej pracy, powiększały w istocie wartość „N”, co w efekcie znacząco obniżało wartość współczynnika aktywności badawczej, której wyniki zostały zobiektywizowane.

Istotnym czynnikiem wynikającym $\mathrm{z}$ analizy ilościowej było określenie tak zwanych jednostek referencyjnych czy wartości stanowiących granice przypisania danej jednostki naukowej do poszczególnych kategorii A, B czy C. Ustalano je na podstawie szczegółowej analizy statystycznej poszczególnych wartości według każdego z kryterium oceny. Kategoria A+ była określana w grupie jednostek zali- 
czanych w pierwszym kroku do kategorii A, a potem poddanych dodatkowej ocenie przez ekspertów KEJN.

Wyniki kompleksowej oceny jednostek naukowych ukazały się 16 października 2017 r. na stronach internetowych Ministerstwa Nauki i Szkolnictwa Wyższego. Jest to efekt pracy członków Komitetu Ewaluacji Jednostek Naukowych. Ocena ta wyrażona w przyznanej danej jednostce naukowej kategorii ma wartość informatyczną, bowiem każda instytucja podlegająca ewaluacji otrzyma drogą pocztową decyzję administracyjną i może odwołać się od tej oceny do Ministra Nauki i Szkolnictwa Wyższego, przedstawiając dodatkowe informacje albo też kwestionując działalność ekspertów KEJN.

Opierając się na wynikach kompleksowej oceny jednostek naukowych, zamieszczonych w komunikacie Komitetu Ewaluacji Jednostek Naukowych, można dokonać analizy tegoż materiału pod kątem zarówno wartości poszczególnych jednostek w każdym z kryteriów tej oceny, jak też zastosować miary pośrednie, nieobecne $\mathrm{w}$ treści komunikatu, ale oddające uśrednioną moc naukową poszczególnych uczelni według grup: uniwersytety, politechniki, uczelnie artystyczne, ekonomiczne, rolnicze czy pedagogiczne. Można też dokonać analizy materiału statystycznego, biorąc pod uwagę tylko jedną dyscyplinę naukową występującą w wielu jednostkach organizacyjnych zarówno uczelni, jak i Polskiej Akademii Nauk. Tak też uczyniono w tym artykule.

\section{Uśredniona wartość efektywności naukowej i potencjału badawczego uniwersytetów polskich}

Z analizy danych Komitetu Ewaluacji Jednostek Naukowych wynika, że ocenie poddano 993 jednostki naukowe. Niektóre z nich funkcjonowały jako międzywydziałowe, a nawet międzyuczelniane instytuty badawcze, skupiające kadrę kilku wydziałów danej uczelni albo wydziały z kilku uczelni i innych podmiotów funkcjonujących w obszarze nauki w danym mieście.

Każda oceniana jednostka uzyskiwała końcowy wynik w postaci przyznania jej określonej kategorii. W roku 2017 zastosowano cztery oceny efektywności pracy naukowej w danej placówce badawczej. Kategoria „A+” była przyznana jednostkom o najwyższym standardzie prowadzenia badań, których pracownicy publikowali swoje prace w wysoko punktowanych czasopismach naukowych, placówkom o wysokim potencjale kadrowym i znaczącej aktywności w pozyskiwaniu środków na badania od różnych podmiotów państwowych i gospodarczych. Kategorię „A" otrzymywała jednostka naukowa o wysokim poziomie badań, ze znaczącą kadrą naukową i szerokim profilu współpracy ze środowiskiem lokalnym. Kategoria „B” była nadawana placówkom realizującym badania naukowe na przyzwoitym poziomie, zatrudniającym pracowników o wysokich aspiracjach badawczych i osiągającym pewne sukcesy $\mathrm{w}$ działalności badawczej uznawanej przez renomowane 
środowiska naukowe. Natomiast kategorię „C” otrzymywały placówki o niewielkim potencjale kadrowym, niskich przychodach na działalność naukowo-badawczą i w związku z tym o niewielkim dorobku naukowym. Publikacje pracowników tej jednostki ukazywały się przeważnie w nisko punktowanych czasopismach.

Spośród wszystkich ocenianych jednostek naukowych posiadających własny kod sprawozdawczy tylko 47 uzyskało ocenę A+, najwyższą kategorię. Stanowi to zaledwie 4,73\% wszystkich poddanych wszechstronnej analizie placówek badawczych w Polsce. Eksperci KEJN wyodrębnili te jednostki, dokonując głębokiej analizy przedstawionego materiału przez władze tych placówek, poddanego wielostronnej weryfikacji.

Spora grupa jednostek naukowych, bo 332 uzyskała kategorię A. Stanowi to $33,43 \%$ wszystkich ocenianych placówek naukowych. W kategorii B mieści się 467 jednostek naukowych (47,02\%), zaś w C - 147 placówek (14,80\%).

Najwyżej sklasyfikowane zostały jednostki Polskiej Akademii Nauk. Aż 15,18\% $\mathrm{z}$ nich uzyskało kategorię $\mathrm{A}+, 48,10 \%$, kategorię $\mathrm{A}, 22,78 \%$, kategorię $\mathrm{B}$, a tylko $1,86 \%$ kategorię $\mathrm{C}$.

Natomiast wśród 781 jednostek naukowych z poszczególnych szkół wyższych zaledwie 3,87\% mieści się w kategorii A+, 31,9\% w kategorii A, 49,0\% w kategorii B i aż 15,2\% w kategorii C.

Uczelnie można pogrupować w określone kategorie. Są zatem uniwersytety bezprzymiotnikowe, uniwersytety przymiotnikowe, kiedy to właśnie rozwinięcie nazwy uczelni wskazuje na prowadzony w niej obszar badań i dydaktyki, na przykład techniczny, rolniczy, przyrodniczy czy pedagogiczny, akademie, politechniki, wyższe szkoły niepubliczne czy wyższe szkoły zawodowe. Według obecnie obowiązującego prawa szkoła wyższa, która posiada uprawnienia do nadawania stopnia doktora w co najmniej 12 dyscyplinach, może używać nazwy uniwersytet, a jeśli tych uprawnień ma więcej niż 6, ale mniej niż 12, także nazwy uniwersytet przymiotnikowy, na przykład pedagogiczny, przyrodniczy, technologiczny, rolniczy czy artystyczny.

W Polsce 20 szkół wyższych ma w swej nazwie słowo uniwersytet, chociaż nie wszystkie z nich spełniają kryterium posiadania owych 12 uprawnień do nadawania stopnia doktora w poszczególnych dziedzinach i dyscyplinach naukowych. Zostały jednak powołane przez Parlament Rzeczypospolitej i nadano im w ustawie sejmowej taki właśnie status akademicki. Określono też w ustawie termin - rok 2021, do którego muszą spełnić warunki formalne dla uczelni, które mają w swej nazwie słowo „uniwersytet”.

Owe 20 uczelni charakteryzuje się zróżnicowaną strukturą organizacyjną. Posiadają wydziały jako podstawowe jednostki organizacyjne albo instytuty, ośrodki i centra badawcze. Łącznie oceniono 241 podmiotów uniwersyteckich. Spośród nich tylko 13 jednostek organizacyjnych posiada kategorię A+ (5,39\%), najwięcej, bo 5, Uniwersytet Warszawski, 93 wydziały polskich uniwersytetów otrzymały w ocenie parametrycznej kategorię A (38,58\%), w tym aż 15 z Uniwersytetu 
Warszawskiego, 122 jednostki mieszczą się w kategorii B, co stanowi ponad połowę wszystkich wydziałów uniwersyteckich w Polsce (50,62\%), a 13 jednostek uzyskało kategorię C (5,39\%).

Wydziały, instytuty i centra badawcze polskich uniwersytetów uzyskały zatem oceny wyższe niż średnia arytmetyczna dla wszystkich jednostek naukowych w kraju i tym samym przeciętny, uśredniony wynik dla ogółu ocenianych szkół wyższych.

Poszczególne uczelnie realizują własną politykę naukową w zakresie powoływania lub zwijania podstawowych jednostek organizacyjnych. Potencjał badawczy jest skupiony w obszary lub dziedziny naukowe i wtedy w obrębie wydziału mieści się kilka kierunków kształcenia i dyscyplin naukowych albo bywa rozproszony i wówczas dana jednostka prowadzi badania w obrębie jednej dyscypliny i na ogół jeden kierunek kształcenia akademickiego z licznymi specjalnościami.

Poniżej zostanie przedstawiona lista polskich uniwersytetów ustalona na podstawie wartości współczynnika wartości ich efektywności naukowej i potencjału badawczego. Obliczono go następująco: każdy wydział uczelni umieszczony na liście KEJN został przypisany do jednej z czterech kategorii: A+, A, B i C. Jeśli dany wydział został oceniony najwyżej przez ekspertów i mieści się w kategorii A+, otrzymywał 3 punkty, jeśli był w kategorii A - 2 punkty, jeśli w kategorii B to jeden punkt, a w kategorii C - 0 punktów. Liczbę wydziałów z danej uczelni z określoną kategorią mnożono przez przypisane im punkty, potem sumowano wartości z poszczególnych kategorii, a ów wynik dzielono przez liczbę jednostek organizacyjnych tej uczelni poddanych ocenie parametrycznej przez KEJN. Uzyskiwano wskaźniki mieszczące się w przedziale od 0 do 3. Jeśli zatem wszystkie wydziały danej uczelni otrzymałyby kategorię $\mathrm{C}$, to współczynnik wartości ich efektywności naukowej i potencjału badawczego wynosiłby 0 , a jeśli wszystkie wydziały mieściłyby się w kategorii A+, to ów współczynnik wynosiłby 3. Zatem wartość współczynnika bliższa 3 świadczy o bardzo wysokiej ocenie parametrycznej wszystkich wydziałów danej uczelni.

Lista polskich uniwersytetów w układzie od najwyższej wartości współczynnika wartości efektywności naukowej i potencjału badawczego do najniższej jest następująca. Ustalono je na podstawie danych zamieszczonych przez Komitet Ewaluacji Jednostek Naukowych, czyli organ państwowy. Dane w ankiecie ewaluacyjnej obejmują lata 2013-2016, a tutaj uwzględnia się szczególnie dorobek naukowy, potencjał badawczy, efektywność współpracy z podmiotami gospodarczymi i otoczeniem społecznym, jak też inne osiągnięcia spoza trzech już wymienionych obszarów oceny tej jednostki.

Uniwersytet Jagielloński w Krakowie - 2,17 (3 wydziały z kategorią A+)

Uniwersytet im. Adama Mickiewicza w Poznaniu - 1, 87 (2 wydziały z kategorią A+)

Uniwersytet Warszawski - 1,83 (5 jednostek z kategorią A+)

Uniwersytet Mikołaja Kopernika w Toruniu - 1,70 (2 wydziały z kategorią A+) 


\begin{abstract}
Uniwersytet Łódzki - 1,66
Uniwersytet Gdański - 1,63 (1 wydział z kategorią A+)

Uniwersytet Wrocławski - 1,50

Uniwersytet Śląski w Katowicach - 1,41

Uniwersytet Papieski Jana Pawła II w Krakowie - 1,33

Uniwersytet Kazimierza Wielkiego w Bydgoszczy - 1,28

Uniwersytet w Białymstoku - 1,22

Uniwersytet Kardynała Stefana Wyszyńskiego w Warszawie - 1,20

Uniwersytet Jana Kochanowskiego w Kielcach - 1,14

Uniwersytet Warmińsko-Mazurski w Olsztynie - 1,12

Uniwersytet Szczeciński - 1,10

Uniwersytet Marii Curie-Skłodowskiej w Lublinie - 1,09

Katolicki Uniwersytet Lubelski im. Jana Pawła II - 1,00

Uniwersytet Zielonogórski - 1,00

Uniwersytet Opolski - 0,87

Uniwersytet Rzeszowski - 0,83

Średnia arytmetyczna wynosi 1,29. Zatem każdy wynik wyższy od tej wielkości lokuje daną uczelnię ponad przeciętność akademicką. Mieści się tutaj 9 uniwersytetów najwyżej sklasyfikowanych ze względu na współczynnik wartości efektywności badań naukowych i potencjału badawczego uczelni.

Największą uczelnią pod względem liczby podstawowych jednostek organizacyjnych jest Uniwersytet Warszawski, bo posiada aż 30 wydziałów, instytutów i wyodrębnionych centrów badawczych, Uniwersytet Jagielloński w Krakowie oraz Uniwersytet Mikołaja Kopernika w Toruniu posiadają 17 wydziałów, a Uniwersytet im. Adama Mickiewicza w Poznaniu i Uniwersytet Warmińsko-Mazurski w Olsztynie po 16 wydziałów. Najmniej jednostek organizacyjnych posiada Uniwersytet Papieski Jana Pawła II w Krakowie, bo 6, a Uniwersytet Kazimierza Wielkiego w Bydgoszczy oraz Uniwersytet Jana Kochanowskiego w Kielcach 7 wydziałów.
\end{abstract}

\title{
Wyniki oceny parametrycznej jednostek naukowych prowadzących badania i kształcenie akademickie w obrębie pedagogiki
}

Analizie poddano 28 jednostek organizacyjnych, zarówno z uczelni publicznych, jak i niepublicznych prowadzących badania naukowe jak i studia z zakresu pedagogiki. Wydziały akademickie są jednorodne, jeśli skupiają badaczy wyłącznie z pedagogiki albo różnorodne, kiedy prowadzi się tam więcej niż jeden kierunek studiów oraz badania w kilku dyscyplinach nauk humanistycznych i społecznych.

Szczegółowiej analizuje się wielkość danej placówki dydaktyczno-badawczej, czyli wysokość uśrednionej dla trzech lat liczby „N”, czyli pracowników zatrudnionych na etatach naukowych i naukowo-dydaktycznych. Następnie wnikliwej 
analizie poddano cztery kryteria oceny parametrycznej jednostek naukowych prowadzonej przez Komitet Ewaluacji Jednostek Naukowych.

Jedna jednostka - Instytut Badań Edukacyjnych w Warszawie nie prowadzi studiów wyższych w znaczeniu ustawowym. Realizuje badania naukowe i kształcenie na studiach podyplomowych, ale nie na studiach I i II stopnia. Nie został zatem wliczony do wspólnej grupy z uczelniami. Ale jego osiągnięcia są znaczące. Instytut Badań Edukacyjnych zatrudnia 34 osoby na stanowiskach naukowych. Badacze ci uzyskali w kryterium 1, czyli sumarycznego dorobku naukowego 61,05 punktów, w kryterium drugim - potencjału badawczego - 297 punktów, w kryterium trzecim - pozyskiwaniu środków na badania naukowe i efektywnej współpracy z innymi podmiotami 93 i w kryterium czwartym - ocenie pozostałej działalności jednostki - 70. W efekcie Instytut Badań Edukacyjnych uzyskał kategorię A.

Największe jednostki prowadzące badania i kształcenie akademickie z obszaru pedagogiki oraz innych nauk humanistycznych i społecznych to Wydział Nauk Historycznych i Pedagogicznych Uniwersytetu Wrocławskiego. Wartość „N” wynosi tutaj 253. Kolejny jest wydział Nauk Społecznych Uniwersytetu Gdańskiego, gdzie wartość „N” to 244, następnie Wydział Filozoficzny Uniwersytetu Jagiellońskiego w Krakowie - „N” 236 i Wydział Nauk Społecznych KUL im. Jana Pawła II - „N” 202. Wszystkie te wydziały są różnorodne, czyli skupiają badaczy z wielu dyscyplin naukowych. Pozostałe jednostki są mniej liczne. Najmniejsze są wydziały jednorodne zatrudniające niemal wyłącznie przedstawicieli pedagogiki. Najniższą wartość „N” posiadał Wydział Nauk Pedagogicznych z Uniwersytetu Kardynała Stefana Wyszyńskiego w Warszawie - „N” 32, Wydział Nauk Społecznych Uniwersytetu Papieskiego Jana Pawła II w Krakowie - „N” - 40, Wydział Nauk Pedagogicznych UMK w Toruniu - „N” 49.

Najwyższy wskaźnik osiągnięć naukowych uzyskał Wydział Filozoficzny Uniwersytetu Jagiellońskiego w Krakowie, bo 55,7 pkt przeliczeniowych, następny był Wydział Nauk Pedagogicznych UMK w Toruniu - 51,06, Wydział Pedagogiki i Psychologii Uniwersytetu Kazimierza Wielkiego w Bydgoszczy - 48,34 oraz Wydział Nauk Społecznych Uniwersytetu Gdańskiego - 47,66. Z kolei najniższą wartość tego wskaźnika zanotowano na Wydziale Nauk Społecznych Akademii Pomorskiej w Słupsku - 28,96, na Wydziale Nauk Społecznych Uniwersytetu Papieskiego Jana Pawła II w Krakowie - 34,2, na Wydziale Nauk Społecznych Uniwersytetu Opolskiego - 34,21 oraz na Wydziale Pedagogiki i Psychologii UMCS w Lublinie - 36,25.

Wartość uśredniona dla wszystkich analizowanych jednostek organizacyjnych poszczególnych uczelni wynosi 40,84. Aż 14 ocenianych wydziałów znajduje się powyżej tej wartości.

Kryterium drugie szczegółowej oceny jednostek naukowych prowadzących studia i badania naukowe z zakresu pedagogiki stanowi potencjał kadrowy, a zatem liczba pracowników posiadających tytuł naukowy i stopnie naukowe oraz przeprowadzonych w danej jednostce postępowań o nadanie tytułu profesora, stopnia 
doktora habilitowanego i doktora. A tutaj najwyższy wskaźnik uzyskał Wydział Humanistyczny Uniwersytetu Szczecińskiego - 936, następnie Wydział Nauk Społecznych Katolickiego Uniwersytetu Lubelskiego im. Jana Pawła II - 924 oraz Wydział Filozoficzny Uniwersytetu Jagiellońskiego w Krakowie 901. Są to zatem jednostki różnorodne pod względem prowadzonych kierunków studiów i realizacji badań naukowych z wielu dyscyplin wiedzy.

Najniższy wskaźnik w tym kryterium oceny parametrycznej uzyskał Wydział Pedagogiczny Uniwersytetu Rzeszowskiego - 63, potem Wydział Nauk Społecznych Uniwersytetu Papieskiego Jana Pawła II w Krakowie - 86 oraz Wydział Pedagogiczny Akademii im. Jana Długosza w Częstochowie - 95. Mieszczą się tu zatem wydziały przeważnie jednorodne, prowadzące studia akademickie i badania naukowe tylko z zakresu pedagogiki.

Wartość uśredniona tego wskaźnika wynosi 390. Aż 11 wydziałów znajduje się powyżej tej wartości.

Kryterium trzecie stanowią praktyczne efekty działalności naukowej, zatem pozyskane środki na badania naukowe od organów państwa oraz podmiotów gospodarczych, jak i efekty współpracy z jednostkami samorządu terytorialnego, w tym z placówkami oświatowymi.

Najwyższy wskaźnik uzyskał Wydział Filozoficzny Uniwersytetu Jagiellońskiego w Krakowie - 1,41, następny był Wydział Nauk Historycznych i Pedagogicznych Uniwersytetu Wrocławskiego - 1,16 oraz Wydział Nauk Społecznych Uniwersytetu Opolskiego - 1,09. Z analizy danych uzyskanych z informacji KEJN wynika, że dwa wydziały polskich uniwersytetów, bo Wydział Pedagogiki, Psychologii i Socjologii Uniwersytetu Zielonogórskiego oraz Wydział Pedagogiczny Uniwersytetu Rzeszowskiego nie uzyskały żadnego punktu w tym zakresie.

Uśredniony wskaźnik wyniósł w tym kryterium 0,34 i wyżej ulokowało się 9 jednostek organizacyjnych poszczególnych uczelni prowadzących studia i badania w obszarze pedagogiki.

Kryterium czwarte stanowiły pozostałe efekty działalności naukowej i artystycznej. Oceny osiągnięć dokonywali eksperci KEJN. Kierownictwo wydziałów składało informacje o najważniejszych sukcesach poszczególnych badaczy i wydarzeniach, w których oni uczestniczyli.

Najwyższy wskaźnik uzyskał tutaj Wydział Filozoficzny Uniwersytetu Jagiellońskiego w Krakowie - 95, następny był Wydział Nauk Historycznych i Pedagogicznych Uniwersytetu Wrocławskiego - 67,4, Wydział Studiów Edukacyjnych UAM w Poznaniu - 67 oraz Wydział Nauk Społecznych Katolickiego Uniwersytetu Lubelskiego im. Jana Pawła II - 63.

Najniższy wskaźnik osiągnął Wydział Pedagogiczny Uniwersytetu Pedagogicznego w Krakowie - 16, Wydział Pedagogiczny Akademii Ignatianum w Krakowie 16 oraz Wydział Etnologii i Nauk o Edukacji Uniwersytetu Śląskiego filia w Cieszynie -23 .

Wartość uśredniona wynosi 42,6 i 12 wydziałów uczelni znajduje się powyżej wartości tego wskaźnika. 
Na podstawie wnikliwej oceny ekspertów dostarczonych informacji w ankietach ewaluacyjnych poszczególnych wydziałów uczelni przyznano każdej z nich określoną kategorię. Wśród wydziałów prowadzących kierunek studiów i badania naukowe z zakresu pedagogiki tylko jedna placówka otrzymała kategorię „A+” - Wydział Filozoficzny Uniwersytetu Jagiellońskiego w Krakowie, cztery wydziały uzyskały kategorię „A” - czyli Wydział Studiów Edukacyjnych UAM w Poznaniu, Wydział Nauk Społecznych Uniwersytetu Gdańskiego, Wydział Nauk Społecznych Katolickiego Uniwersytetu Lubelskiego oraz Wydział Pedagogiki i Psychologii Uniwersytetu Kazimierza Wielkiego w Bydgoszczy. Aż 18 wydziałów uzyskało kategorię „B”, a 5 wydziałów polskich uczelni kategorię „C”.

\section{Wnioski z analizy informacji Komitetu Ewaluacji Jednostek Naukowych o wynikach oceny parametrycznej wydziałów uniwersyteckich}

Środowisko naukowe zostało poinformowane przez Ministerstwo Nauki i Szkolnictwa Wyższego oraz jego rozliczne agendy o cyklicznej ocenie parametrycznej i stosowanych tam kryteriach. Z każdym dniem pracy badawczej poszczególni nauczyciele akademiccy zaznaczali swój trwały wkład w rozwój nauki. Uzyskiwane punkty za publikacje naukowe, pozyskiwane środki na badania czy promocję młodej kadry naukowej pomnażały dorobek danej placówki. Istotna wydaje się rola władz uczelni i wydziałów w promowaniu wiedzy o zasadach finansowania nauki i ocenie parametrycznej będącej w znacznym stopniu podstawą do realizacji badań statutowych. Zdaje się, że część kadry naukowej nie zna podstawowych zasad oceny naukowej ani w ujęciu podmiotowym, związanym z własną karierą akademicką, ani w ujęciu instytucjonalnym - analizy parametrycznej różnych wskaźników opisujących całościowo wkład tej jednostki w rozwój nauki. Wydają się zaskoczeni zarówno faktem cyklicznej oceny własnego wydziału, jak i swoim dorobkiem naukowym, niekiedy opublikowanym w pismach nieumieszczonych na właściwej liście ministra nauki, a zatem pozbawionych punktacji. Konieczna wydaje się nieustanna i intensywna akcja promocji wiedzy o zasadach parametryzacji jednostek naukowych i standardach oceny poszczególnych osób jako podmiotów działających na wspólnym rynku nauki. Skoro właśnie takie istnieją zasady funkcjonowania w środowisku akademickim.

W latach 2007-2013 Polska uzyskała znaczne wsparcie finansowe z Unii Europejskiej. Część tych nadzwyczajnych przychodów państwa została wykorzystana przez uczelnie oraz instytuty badawcze. Były trzy źródła pozyskiwania środków finansowych: Fundusz Spójności Infrastruktura i Środowisko, Rozwój Polski Wschodniej oraz Europejski Fundusz Społeczny. Dwa pierwsze dofinansowywały infrastrukturę naukową, trzeci natomiast rozwój badań naukowych, działalność kulturalną i edukacyjną. Polskie uczelnie i jednostki badawcze otrzymały na reali- 
zację zgłoszonych w konkursach projektów infrastrukturalnych kilkadziesiąt miliardów złotych. Także znaczące kwoty były uruchomione na działania szkoleniowe, na studia podyplomowe jak też badania aplikacyjne.

Została stworzona baza do realizacji projektów badawczych. Ich efekty powinny być właśnie dostrzeżone w ocenie parametrycznej jednostek naukowych w okresie sprawozdawczym 2013-2016.

Występują znaczne różnice w efektywności badań naukowych. Najwyższy wskaźnik w kryterium pierwszym wśród jednostek uniwersyteckich uzyskał Wydział Fizyki i Informatyki Uniwersytetu Łódzkiego - 144 punkty. Wydziały humanistyczne i społeczne mają znacznie gorsze wyniki, bo czasopisma naukowe $\mathrm{z}$ tego obszaru są zdecydowanie niżej punktowane. Zresztą badacze z nauk humanistycznych i społecznych częściej publikują swoje prace w języku polskim. Ich przebicie na „światowym rynku nauki” jest znacznie mniejsze. Spośród jednostek naukowych prowadzących studia i badania z zakresu pedagogiki Wydział Filozoficzny Uniwersytetu Jagiellońskiego w Krakowie uzyskał 55,7 punktów, co oznacza, że w jednym roku sprawozdawczym każda osoba zatrudniona w tej placówce na etacie naukowo-dydaktycznym uzyskiwała średnio 13,9 punktów, przy 36 punktach na Wydziale Fizyki i Informatyki Uniwersytetu Łódzkiego.

Ministerstwo Nauki i Szkolnictwa, komentując wyniki oceny parametrycznej jednostek naukowych, uznało, iż nastąpił pewien postęp w rozwoju badań i promocji kadry naukowej, bo więcej placówek uzyskało najwyższe kategorie A+ i A i więcej też wydziałów wypełniło ankietę ewaluacyjną. Jednak nie istnieje jak dotąd standard osiągnięć naukowych, jakaś obiektywna miara czy wzorzec owej oceny. Środowisko naukowe w Polsce powinno uczestniczyć w pracach nad skonstruowaniem takiego wzorca oceny naukowej przydatnego do pomiaru osiągnięć indywidualnych poszczególnych badaczy jak i całych instytucji naukowych. Konsultacje środowiskowe organów państwowych są tylko rutynowym działaniem informacyjnym, a nie rzeczywistym uzgadnianiem pewnych stanowisk między zainteresowanymi stronami.

Ponieważ ocenie poddawano wydziały uczelni bądź instytuty badawcze, to rzeczywisty obraz osiągnięć w obrębie danej dyscypliny jest zamazany. Na przykład pedagogika w wielu uczelniach występuje jako lider podciągający innych albo bywa też „schowana” za innymi dyscyplinami wiedzy. Wydziały różnorodne uzyskiwały wyższe wartości w poszczególnych kryteriach oceny niż wydziały jednorodne z zakresu badań pedagogicznych. Wyjątkiem jest tutaj wysoka pozycja Wydziału Studiów Edukacyjnych UAM w Poznaniu.

Każda ocena parametryczna przynosi nieco inne wyniki. Jedne wydziały uzyskują awans, inne spadają do niższej kategorii. Tylko dwa wydziały prowadzące studia i badania z zakresu pedagogiki utrzymują od lat swoją wysoką pozycję: Wydział Filozoficzny Uniwersytetu Jagiellońskiego w Krakowie oraz Wydział Studiów Edukacyjnych UAM w Poznaniu. 
Niezwykłą staranność muszą zachować profesjonalni pracownicy z zakresu bibliometrii dokonujący klasyfikacji poszczególnych publikacji i w efekcie przyznający punkty wynikające $\mathrm{z}$ rozporządzenia ministra właściwego do spraw nauki. Zdarzają się bowiem i takie sytuacje, że taką samą liczbę punktów uzyskuje autor 20-stronicowego artykułu przeglądowego, pięciostronicowego doniesienia z badań, jednostronicowego listu do redakcji czy też dwustronicowego wspomnienia o wybitnym, właśnie zmarłym uczonym. Dane te zamieszcza się w bazie expertus, która stanowi podstawę do zaciągania podstawowych informacji do ankiety ewaluacyjnej przez władze danej jednostki organizacyjnej. Eksperci KEJN - u zaliczają do wysoko punktowanych publikacji tylko artykuły naukowe, a nie wszystkie publikacje zamieszczone w danym czasopiśmie.

Pomimo stosowania wielu wskaźników liczbowych w ocenie parametrycznej jednostek naukowych, to jednak nadal jest w tym procesie zbyt wiele uznawalności. Decyzję podejmują eksperci KEJN, a ta oparta bywa na przesłankach całkowicie subiektywnych, dotyczących na przykład kryterium 4 - pozostała działalność naukowa i artystyczna.

Kandydaci na ewaluatorów KEJN są zgłaszani przez różne formalne i nieformalne organy samorządu akademickiego, niekiedy też sami aspirują do tego, aby ich nazwiska zostały wpisane do rejestru osób prowadzonego w tej instytucji. Nieznane są jednak dalsze drogi ich rekrutacji na szczegółowych ekspertów KEJN. Powinna być jasna ścieżka zgłaszania kandydatów, stawiane im wymagania formalne i merytoryczne oraz instancja weryfikująca owe informacje. Takim ciałem opiniodawczym mógłby być Komitet Nauk Pedagogicznych PAN, w przypadku oceny jednostek naukowych prowadzących badania z zakresu tej dyscypliny wiedzy. Członkowie Komitetu są bowiem wybierani przez środowisko naukowe i mają silny mandat społeczny.

Ze względu na ścisły związek uzyskanej kategorii w ocenie parametrycznej i finansowania badań statutowych powinna być prowadzona akcja informacyjna w środowisku akademickim o kryteriach oceny i warunkach prowadzenia i finansowania badań naukowych jak też klarowne ścieżki odwoławcze. Wynik i procedura odwoławcza powinny być umieszczane w mediach elektronicznych i powszechnie dostępne dla całego środowiska akademickiego.

Zarówno zasady oceny nauki, kryteria w parametryzacji jednostek naukowych, jak też pomiar indywidualnych osiągnięć poszczególnych badaczy były przedmiotem refleksji przedstawicieli głównie nauk społecznych, z socjologii nauki czy psychologii. Podkreślali oni nadmierną standaryzację osiągnięć naukowych, wyścig korporacji uczonych po punkty za opublikowane prace czy wynalazki, odpersonalizowanie badań i upowszechniania osiągnięć naukowych czy w ostatnim okresie wszechobecną „punktozę”, czyli zjawisko wymierzania wszystkich działań pracowników naukowych i przypisywania ich do poszczególnych kategorii osiągnięć. I tak, ustawowy wymóg oceny trzech aspektów działalności nauczyciela akademickiego: jego aktywność w sferze badawczej, w procesie dydaktycznym oraz w pracy orga- 
nizacyjnej uczelni wyzwolił mechanizm punktowania każdej najdrobniejszej zobiektywizowanej czynności. Dla każdego z tych obszarów aktywności nauczyciela akademickiego utworzono kilkadziesiąt możliwych form jego zaangażowania i każde z nich uzyskało jakiś wymiar liczbowy. W okresowej ocenie pracy akademików sumuje się punkty z wszystkich tych cząstkowych kryteriów i przyznaje im określoną liczbę punktów. Jeśli dana osoba spełnia wymagania ustalone w tym zakresie przez radę danej jednostki organizacyjnej, to uzyskuje pozytywną ocenę, jeśli zaś nie spełnia któregoś z kryteriów, otrzymuje ocenę negatywną. Zasady te stosuje się także w systemie nadzwyczajnego motywowania pracowników nauki $\mathrm{w}$ formie dodatku do wynagrodzenia zasadniczego.

Zjawisko wszechobecnej w środowisku akademickim „punktozy” było przedmiotem krytyki wielu przedstawicieli nauk humanistycznych i społecznych (Brzeziński 2016; Śliwerski 2017) i pomimo raczej negatywnej opinii w tym zakresie większości uczonych, stało się trwałym elementem pejzażu akademickiego.

Komitet Ewaluacji Jednostek Naukowych określił kryteria oceny parametrycznej jednostek naukowych. W pewnym sensie można je nazwać warunkami brzegowymi, w których funkcjonują jednostki naukowe w Polsce. Władze i pracownicy każdej placówki, decydując się na wypełnienie ankiety ewaluacyjnej, przyjęły do wiadomości owe reguły oceny. Istotnym elementem jest tutaj możliwość powiększenia dzielnej poprzez publikowanie prac naukowych $\mathrm{w}$ najbardziej cenionych w środowisku naukowym czasopismach, o najwyższej punktacji zawartej w Komunikacie Ministra Nauki i Szkolnictwa Wyższego w odniesieniu do listy czasopism i ich punktowej wyceny. Ale można też zmniejszyć dzielnik poprzez umiejętne gospodarowanie kadrami naukowymi. W liczbie „N” powinny zatem znaleźć się tylko osoby najbardziej efektywne w działalności naukowej. Ale to jest już polityka kadrowa w uczelniach i jednostkach naukowych. W wyższych szkołach publicznych funkcjonują związki zawodowe dbające o interesy swoich członków, w tym także dotyczące formuły zatrudnienia, zajmowanych stanowisk w pionie naukowo-dydaktycznym. Uczelnie i instytuty badawcze, dla których organem założycielskim jest ministerstwo nauki albo inny resort, muszą respektować przepisy zawarte w kodeksie pracy i innych dokumentach prawnych regulujących prawa pracownicze. Takie obwarowania nie dotyczą sektora uczelni niepublicznych i laboratoriów należących do prywatnych instytucji. Stąd większa jest tutaj elastyczność w zakresie wliczania poszczególnych badaczy do kategorii „N”. Istnieje zatem pewna możliwość operowania zarówno wartością licznika, jak i mianownika w ustaleniu wysokości ilorazu, czyli wartości pierwszego kryterium kompleksowej oceny instytucji naukowej, czyli zarządzania wartością „N”.

Występuje rozdźwięk między rzeczywistymi osiągnięciami naukowymi w formie wynalazków rewolucjonizujących gospodarkę, kulturę czy codzienne życie ludzi, nowych teorii naukowych wyjaśniających jakieś zjawisko przyrodnicze czy mechanizm społecznego działania, a nawet znakomitymi pracami naukowymi opublikowanymi w najbardziej renomowanych czasopismach. Ich prestiż wynika 
nie tyle z samej zawartości treściowej, ile miejsca publikacji. Liczba zdobytych punktów nie przekłada się w ogóle na jakość wyników badań naukowych. Nieustannie powiększająca się liczba sprofilowanych czasopism, wydawnictw naukowych, liczba badaczy i nauczycieli akademickich pomnaża wiedzę naukową. Jest ona coraz szersza, ale bynajmniej niezbyt głęboka. Nośne hasło rzucone przez decydentów politycznych w przestrzeń naukowego świata „publikuj albo giń" spowodowało wiele zjawisk negatywnych w korporacji uczonych (Górniewicz 2014a). Liczba przeliczeniowych punktów nieustannie się powiększa, ale równocześnie zmniejsza się wielkość środków na badania naukowe przypadająca na owe punkty. Każda publikacja wszak odzwierciedla także wysokość dofinansowania działań naukowych. Dostrzega się już znamiona kolejnego kryzysu w nauce. Rozwiera się luka między zaangażowaniem uczonych w procesy badawcze i uzyskiwanymi wynikami naukowymi a środkami przekazywanymi przez państwo i podmioty gospodarcze do organów finansujących poszczególne projekty. Istnieje granica wewnętrznej motywacji i zobiektywizowanej efektywności o charakterze ekonomicznym. Ta wnet zostanie domknięta przez polityków.

\section{Bibliografia}

Arnold A. (2011) Słownik języka polskiego, Warszawa, Wydawnictwo Szkolne PWN.

Bourdieu P. (2009) Sondaże - „nauka” bez naukowców, tłum. K. Sztander-Sztanderska, „Kultura Popularna”, nr 3.

Brzeziński J. (2016) Przeciwko depersonalizacji i nadmiernej standaryzacji procesu ewaluacji w nauce, „Zagadnienia Naukoznawstwa”, nr 1.

Gil J. (2014) Dwa rankingi naukowe: kategoryzacja wydziałów uczelni a Indeks Hirscha, „Forum Akademickie”, nr 2.

Górniewicz J. (2014a) Kryzys, czy kres idei uniwersytetu w: Pobrzeża badań pedagogicznych, J. Górniewicz, M. Warmiński (red.), Olsztyn, Centrum Badań Społecznych UWM.

Górniewicz J., Piotrowski P. (2014b) Uniwersytet jako źródło wartości kultury, Warszawa-Olsztyn, Pracownia Wydawnicza Elset.

Komunikat Ministra Nauki i Szkolnictwa Wyższego z dnia 18 grudnia 2015 roku w sprawie wykazu czasopism naukowych.

Krzemieniowa K. (1986) Wstęp, do T. W. Adorno, Dialektyka negatywna, Warszawa, PWN. 
Nowak P. (2008) Bibliometria i webometria - podstawy, wybrane zastosowania, Poznań, Wydawnictwo UAM.

Piotrowski P. (2017) Pół wieku rankingów Instytutu Informacji Naukowej - bibliometria jako mechanizm dystrybucji społecznego kapitału nauki w: Temporalne aspekty problematyki szkolnictwa wyższego, P. Piotrowski (red.), Olsztyn, Centrum Badań Społecznych UWM.

Racki G. (2001) Ocena parametryczna - prognozy i postulaty, „Sprawy Nauki”, nr 10.

Rozporządzenie Ministra Nauki i Szkolnictwa Wyższego z dnia 12 grudnia 2016 roku w sprawie przyznawania kategorii naukowej jednostkom naukowym i uczelniom, w których zgodnie $\mathrm{z}$ ich statutami nie wyodrębniono podstawowych jednostek organizacyjnych (Dz.U. 2016, poz. 2154).

Sadowski I., Mach B. W. (2014) Parametryzacja i kategoryzacja jednostek naukowych w roku 2013 jako praktyka ewaluacyjna i proces instytucjonalny: przypadek nauk humanistycznych i społecznych, „Nauka”, nr 2.

Skalska-Zlat M. (2015) Komunikacja piśmiennicza w badaniach bibliometrycznych w: Teoretyczne zagadnienia bibliologii i informatologii. Studia i szkice, E. Gondek (red.), Katowice, Wydawnictwo Uniwersytetu Śląskiego.

Sordylowa B. (1998) Bibliologia a naukoznawstwo, „Przegląd Bibliotekarski”, nr 2-3.

Śliwerski B. (2017) Habilitacja: diagnoza, procedury, etyka, postulaty, Kraków, Oficyna Wydawnicza „Impuls”.

Ustawa z dnia 30 kwietnia 2010 roku o zasadach finansowania nauki (Dz.U. 2016, poz. 2045 z późn. zm.).

Wilkin J. (2013) Ocena parametryczna czasopism naukowych w Polsce: podstawy metodologiczne, znaczenie praktyczne, trudności realizacji i perspektywy, „Nauka”, nr 1.

Zielińska-Kostyło H. (2011) Przesłanie pedagogiki uciśnionych Paula Freire, „Forum Oświatowe", nr 2. 